Article

\title{
Deficit Irrigation and Partial Root-Zone Drying Techniques in Processing Tomato Cultivated under Mediterranean Climate Conditions
}

\author{
Marcella Michela Giuliani, Eugenio Nardella, Anna Gagliardi (iD) and Giuseppe Gatta * \\ Department of Agricultural, Food and Environmental Sciences, University of Foggia, 71122 Foggia, Italy; \\ marcella.giuliani@unifg.it (M.M.G.); eugenio.nardella@unifg.it (E.N.); anna.gagliardi@unifg.it (A.G.) \\ * Correspondence: giuseppe.gatta@unifg.it; Tel.: +39-0881-589237
}

Received: 26 October 2017; Accepted: 27 November 2017; Published: 28 November 2017

\begin{abstract}
Due to climate change, the application of water saving strategies is of particular interest. The aim of this study was to evaluate the effects of deficit irrigation (DI) and partial root-zone drying (PRD) techniques on the crop water stress index (CWSI), water use efficiency (WUE), and quality parameters in processing tomatoes grown in open field conditions in a Mediterranean climate. Two cultivars were grown for two growing seasons under four irrigation regimes as follows: (i) $\mathrm{IR}_{100}$ : full irrigation by restoring $100 \%$ of the maximum tomato evapotranspiration $\left(\mathrm{ET}_{\mathrm{c}}\right)$; (ii) $\mathrm{IR}_{70 \mathrm{DI}}: 70 \%$ of the amount of water given to the $\mathrm{IR}_{100}$; (iii) $\mathrm{IR}_{70 \mathrm{PRD}}$ : $70 \%$ of the amount of water given to the $\mathrm{IR}_{100}$ by applying partial root-zone drying and (iv) $\mathrm{IR}_{0}$ : irrigation only at transplanting and during fertigation. During the flowering period, the first growing season was characterized by an absence of rainfall and by higher temperatures also showing a higher CWSI. Despite, under $I_{70 P R D}$, the CWSI was significantly higher than under $\mathrm{IR}_{70 \mathrm{DI}}$, the marketable yield obtained was significantly higher. Both $\mathrm{IR}_{70 \mathrm{DI}}$ and $\mathrm{IR}_{70 \mathrm{PRD}}$ regimes received approximately $24 \%$ less water than $\mathrm{IR}_{100}$, but the yield reduction with relation to the optimum regime was equal to $16.2 \%$ under $\mathrm{IR}_{70 \mathrm{DI}}$, and only $7.6 \%$ under $I_{70 P R D}$. The WUE increment of $I_{70 P R D}$ with respect to $I_{100}$ was equal to $27 \%$ in the first growing season and to $17 \%$ in the second one, showing that the positive effect of PRD on the WUE is more evident in the more stressed year. Finally, the results from the principal component analysis (PCA) showed that the two cultivars had different qualitative responses in the two extreme regimes $\left(\mathrm{IR}_{100}\right.$ and $\left.\mathrm{IR}_{0}\right)$ but not under PRD and DI regimes.
\end{abstract}

Keywords: water saving; water use efficiency; crop water stress index; deficit irrigation; partial root-zone drying; stomatal conductance; principal component analysis

\section{Introduction}

Irrigated agriculture plays a major role in food production, and in the Mediterranean Basin this type of agriculture uses between $50 \%$ and $90 \%$ of all water resources [1]. Worldwide, water availability is decreasing more and more, especially in semi-arid Mediterranean areas. In these areas, due to climate change, the frequency and severity of prolonged periods of drought, as well as strong seasonal variation in the water budget, are predicted [2-4]. In this context, both use of the non-conventional waters (e.g., treated wastewater) and appropriate techniques of water saving, can be used to reduce the gap between the supply and demand of irrigation water $[5,6]$. The tomato (Solanum lycopersicum L.) is one of the most important vegetable crops worldwide and one of the most demanding of water [7]. The seasonal water requirement for processing tomato is estimated to be approximately 5000 to $6000 \mathrm{~m}^{3} \mathrm{ha}^{-1}$, which, in semi-arid areas, is almost totally supplied by irrigation [6].

Deficit irrigation practices deliberately allow crops to sustain some degree of water deficit, sometimes with light yield loss and with significant reduction in irrigation water use [6,8-10]. 
Another water-saving practice is partial root-zone drying (PRD), which consists in the exposure of half of the root system to alternate drying and wetting cycles. Theoretically, roots of the watered side of soil will keep a favourable plant status, while dehydratation of the other side will promote the synthesis of abscisic acid (ABA), which will reach leaves by the transpiration stream and further reduce stomata conductance [11,12]. When studying the deficit irrigation application, knowledge of crop water status plays a key role. Visible near-infrared and thermal spectral sensing techniques can be useful tools to assess plant status [13]. The crop water stress index (CWSI) is one of the most used crop indices, based on thermal data from the canopy $[14,15]$. In the literature, changes in CWSI were significantly associated with changes in water status [16]. Under water stress conditions, plants tend to reduce their transpiration rate, closing their stomata, which also reduces the plant's transpiration cooling ability, causing an increase in leaf temperature.

PRD practice has been successfully tested on a range of crops, especially tree crops, including apples [17], passion fruit [18], grapevines [19-21], oak [22], birch [23], and olive trees [24,25]. The results from several studies showed that crops under PRD yielded better than under DI when the same amount of water is applied, indicating higher water use efficiency (WUE) and even better fruit quality [26]. Several studies also examine the effects of deficit irrigation on tomato production. However, the available literature presents some discrepancies, linked to the cultivars used and/or to the phenological period of application of deficit irrigation treatments [7]. Moreover, most of these studies are in greenhouses or under controlled conditions [27-34]. Notwithstanding, there is still little understanding on the mechanisms of PRD in different tomato cultivars grown under open field conditions, and any agro-climatic parameters (e.g., air temperature) can influence the plant response. Therefore, additional studies are necessary to better define deficit irrigation practices and acceptable levels of water stress in processing tomato crops.

In a preliminary study, we evaluate the effect of DI and PRD on yield response in processing tomato [35]. In this work, we study the effects of PRD and DI on stomatal conductance, CWSI, WUE (as the ratio between marketable yield and total water received by the crop) and quality parameters in processing tomato grown in open field conditions in a Mediterranean climate. The effect of the growing season was also evaluated.

\section{Materials and Methods}

\subsection{Site Description}

The research was conducted in Southern Italy (Foggia, $41^{\circ} 46^{\prime} \mathrm{N}, 15^{\circ} 54^{\prime} \mathrm{E}$; altitude $74 \mathrm{~m}$ above sea level) over two growing seasons $\left(\mathrm{GS}_{1}, 2008\right.$ and $\mathrm{GS}_{2}, 2009$ ) on a loam soil (United States Department of Agriculture Classification) in which chemical and physical characteristics were as follows, respectively, during the two years: $\mathrm{pH} 7.5$ and 7.2; organic matter (Walkley-Black method) $1.9 \%$ and 1.6\%; total nitrogen (Kjeldahl method) $1.3 \%$ and $1.2 \%$; assimilable phosphorus (Olsen method, $\mathrm{P}_{2} \mathrm{O}_{5}$ ) $80 \mathrm{mg} \mathrm{kg}^{-1}$ and $88 \mathrm{mg} \mathrm{kg}^{-1}$; exchangeable potassium (chloride of barium method) $461 \mathrm{mg} \mathrm{kg}^{-1}$ and $421 \mathrm{mg} \mathrm{kg}^{-1}$; field capacity ( $\left.-0.03 \mathrm{MPa}\right) 35.2 \%$ dry weight (d.w.) and $36.7 \%$ d.w.; wilting point $(-1.5 \mathrm{MPa}) 19.2 \%$ d.w. and $18 \%$ d.w. The experimental site was characterized by a Mediterranean climate, with a long-term mean annual rainfall of $537 \mathrm{~mm}$ [36], which was mainly distributed from October to April.

\subsection{Irrigation Treatments and Crop Management}

Four irrigation regimes on two processing tomato (Solanum lycopersicum L.) cultivars, 'Ercole' (Syngenta Seeds SpA) and 'Genius' (ISI Sementi SpA), were studied as follows: (i) full irrigation ( $\mathrm{IR}_{100}$ ), by restoring $100 \%$ of the maximum crop evapotranspiration $\left(\mathrm{ET}_{\mathrm{C}}\right)$; (ii) $\mathrm{IR}_{70 \mathrm{DI}}: 70 \%$ of the amount of water given to the $\mathrm{IR}_{100}$; (iii) $\mathrm{IR}_{70 \mathrm{PRD}}$ : $70 \%$ of the amount of water given to the $\mathrm{IR}_{100}$ by applying partial root-zone drying; (iv) $\mathrm{IR}_{0}$ : irrigation only at transplanting $\left(250 \mathrm{~m}^{3} \mathrm{ha}^{-1}\right.$ and $220 \mathrm{~m}^{3} \mathrm{ha}^{-1}$ in $\mathrm{GS}_{1}$ and 
$\mathrm{GS}_{2}$, respectively), and during fertigation $\left(222 \mathrm{~m}^{3} \mathrm{ha}^{-1}\right.$ and $180 \mathrm{~m}^{3} \mathrm{ha}^{-1}$, in $\mathrm{GS}_{1}$ and $\mathrm{GS}_{2}$, respectively) (Table 1).

A split-plot design with three replicates, consisting of the irrigation regimes in the plot and the cultivars in the sub-plot, was used.

Irrigation was applied when the water lost by $\mathrm{ET}_{\mathrm{c}}$ in the root zone reached the predetermined level ( $40 \%$ of the available water depletion). The irrigation volumes (Table 1) were calculated by subtracting the effective rainfalls from the $\mathrm{ET}_{\mathcal{C}}$, as calculated using Equation (1) [37]:

$$
\mathrm{ET}_{\mathrm{c}}=\mathrm{ET}_{\mathrm{o}} \times \mathrm{K}_{\mathrm{c}}
$$

where the reference crop evapotranspiration $\left(\mathrm{ET}_{\mathrm{o}}\right)$ was calculated using the Penman-Monteith equation, and $\mathrm{K}_{\mathrm{c}}$ is the crop coefficient, as detected in an environment similar to our experimental site [38].

The seasonal tomato water received, under the different irrigation regimes, was calculated using the soil water balance equation [39]:

$$
\mathrm{ET}=\mathrm{I}+\mathrm{P}+\mathrm{Cr}-\mathrm{R}-\mathrm{D} \pm \Delta \mathrm{S}
$$

where I is the irrigation water amount $(\mathrm{mm}) ; \mathrm{P}$ is the precipitation $(\mathrm{mm}) ; \mathrm{Cr}$ is the capillary rise $(\mathrm{mm})$; $\mathrm{R}$ is the amount of runoff $(\mathrm{mm})$; $\mathrm{D}$ is the amount of drainage water $(\mathrm{mm})$ and $\Delta \mathrm{S}$ is the difference between soil water content values, determined gravimetrically, at planting and at harvesting $(\mathrm{mm})$ in the first $0.6 \mathrm{~m}$ depth. In this study, $\mathrm{Cr}$ was considered to be zero due to the high depth of groundwater. Surface runoff was assumed to be negligible because there were no intense rainfall events to cause run-off. Drainage below the root zone was assumed negligible, since water applied with each irrigation was equal to water deficit in 0-0.6 m soil profile of the full irrigated treatment and rainfall amounts were not sufficient to bring the soil moisture level over the field capacity within the root zone during the growing season $[39,40]$. Finally, the difference between soil water content values at planting and at harvesting was also negligible.

A drip irrigation system was used for irrigation, and to adapt the PRD treatment in our crop establishment, two small-diameter pipes were laid down in parallel along the middle of the coupled rows. The two pipes, with drippers with a $4 \mathrm{~L} \mathrm{~h}^{-1}$ flow rate spaced at $1 \mathrm{~m}$, were arranged in such a way that there was always one dripper between four plants of the coupled rows, but they were installed alternately on the two separate pipes [35].

Table 1. Seasonal water received by the tomato crop and irrigation volume over the two experimental

\begin{tabular}{|c|c|c|c|}
\hline $\mathrm{GS}^{1}$ & Irrigation Regime ${ }^{2}$ & $\begin{array}{l}\text { Irrigation Water } \\
\left(\mathrm{m}^{3} \mathrm{ha}^{-1}\right)\end{array}$ & $\begin{array}{l}\text { Water Received (Irrigation + Rainfall) } \\
\qquad\left(\mathrm{m}^{3} \mathrm{ha}^{-1}\right)\end{array}$ \\
\hline $\mathrm{GS}_{1}$ & $\mathrm{IR}_{100}$ & 4918.4 & 5553.4 \\
\hline $\mathrm{GS}_{1}$ & $\mathrm{IR}_{70 \mathrm{DI}}$ & 3548.8 & 4183.8 \\
\hline $\mathrm{GS}_{1}$ & $\mathrm{IR}_{70 \mathrm{PRD}}$ & 3548.8 & 4183.8 \\
\hline $\mathrm{GS}_{1}$ & $\mathrm{IR}_{0}$ & 472.0 & 1107.0 \\
\hline $\mathrm{GS}_{2}$ & $\mathrm{IR}_{100}$ & 4650.0 & 5602.3 \\
\hline $\mathrm{GS}_{2}$ & $\mathrm{IR}_{70 \mathrm{DI}}$ & 3375.0 & 4327.2 \\
\hline $\mathrm{GS}_{2}$ & $\mathrm{IR}_{70 \mathrm{PRD}}$ & 3375.0 & 4327.2 \\
\hline $\mathrm{GS}_{2}$ & $\mathrm{IR}_{0}$ & 400.0 & 1352.0 \\
\hline
\end{tabular}
growing seasons (GS).

${ }^{1} \mathrm{GS}_{1}$, first growing season (2008); $\mathrm{GS}_{2}$, second growing season (2009); ${ }^{2} \mathrm{IR}_{100}$, full irrigation by restoring $100 \%$ of $\mathrm{ET}_{\mathrm{c}} ; \mathrm{IR}_{70 \mathrm{DI}}, 70 \%$ of the amount of water given to the $\mathrm{IR}_{100} ; \mathrm{IR}_{70 \mathrm{PRD}}, 70 \%$ of the amount of water given to the $\mathrm{IR}_{100}$ by applying partial root-zone drying; $\mathrm{IR}_{0}$, watering only at transplanting and during fertigation.

The irrigation water applied was measured with a flow meter. Depending on the irrigation regime, we had the possibility of applying irrigation water through either a single pipe or the two pipes together. If the two pipes were simultaneously used, all sides of the roots were irrigated, as practised under $\mathrm{IR}_{100}$ and $\mathrm{IR}_{70 \mathrm{DI}}$. Applying water through a single pipe, we watered only one side 
of the root zone as required under PRD treatment. The wetted side of the root zone was changed by turning on the coupled pipes, which were alternated.

In conformity with the traditional crop establishment used in the zone, tomatoes were planted on 5 May 2008 and on 12 May 2009 in coupled rows spaced at $160 \mathrm{~cm}$; the distance between the two rows was $50 \mathrm{~cm}$, and the distance between the plants along the row was $50 \mathrm{~cm}$. The final plant density was of 2.5 plants $\mathrm{m}^{-2}$. During the crop seasons, ordinary agricultural practices were performed. The soil was ploughed at a depth of $0.45 \mathrm{~m}$ in the winter of the previous year and, a few days before the transplanting, was well-harrowed at its surface.

The soil was fertilized in pre-transplant using $200 \mathrm{~kg} \mathrm{ha}^{-1}$ of biammonium phosphate (18-46-0) and $300 \mathrm{~kg} \mathrm{ha}^{-1}$ of organic fertilizer (bird guano). After this, throughout the cycle, $100 \mathrm{~kg} \mathrm{ha}^{-1}$ of monoammonium phosphate (12-61-0), $100 \mathrm{~kg} \mathrm{ha}^{-1}$ of ammonium sulphate (21-0-0), $100 \mathrm{~kg} \mathrm{ha}^{-1}$ of ammonium nitrate (26-0-0), and $100 \mathrm{~kg} \mathrm{ha}^{-1}$ of calcium nitrate (15-0-0) were added by fertigation. Pest and weed control were performed according to current management practices. The crop was hand-harvested when the ripe fruit rate reached approximately 95\% (18 August 2008; 22 August 2009).

\subsection{Physiological, Quantitative, and Qualitative Parameters}

Before the irrigations, abaxial stomatal conductance $\left(g_{s}\right)$ observations [29] of the first fully-expanded leaf (three per replicate selected randomly) were recorded between 12:00 and 13:00 (maximum intensity of sunlight). These measurements were made using a steady state diffusion porometer (Model SC-1, Decagon Devices, Inc., Pullman, WA, USA), on three sampling dates (23 June, 4 July, 18 July and 18 June, 8 July, 24 July for $\mathrm{GS}_{1}$ and $\mathrm{GS}_{2}$, respectively), during the period of flowering-fruit breaking colours, considered to be the most sensitive stage of water stress for tomatoes [41]. At the same time, canopy temperatures $\left(T_{c}\right)$ were measured with a hand-held infrared thermometer (IRT) (Scheduler model 2, Delta-T Devices Ltd., Cambridge, UK), which has a detect radiation in the 8-14 $\mu$ waveband. The CWSI was calculated by an empirical method (Equation (3)), as suggested by Idso et al. [14]:

$$
\text { CWSI }=\frac{\left(T_{c}-T_{a}\right)-\left(T_{c}-T_{a}\right)_{U L}}{\left(T_{c}-T_{a}\right)_{U L}-\left(T_{c}-T_{a}\right)_{L L}}
$$

where LL corresponds to the non-water-stressed baseline (lower baseline), and UL corresponds to the non-transpiring upper baseline; $\mathrm{T}_{\mathrm{C}}$ is the canopy temperature $\left({ }^{\circ} \mathrm{C}\right)$ and $\mathrm{T}_{\mathrm{a}}$ is the air temperature $\left({ }^{\circ} \mathrm{C}\right)$. The lower baseline was determined using data collected only from the unstressed treatments $\left(\mathrm{IR}_{100}\right)$. The upper baseline was computed according to the procedures explained by Idso et al. [14]. The CWSI values range between zero (condition of optimal crop water status) and one (condition of high crop water stress). After the harvest, the marketable and discarded fruits were counted and weighed to estimate the total yield $\left(\mathrm{t} \mathrm{ha}^{-1}\right)$ and marketable yield $\left(\mathrm{t} \mathrm{ha}^{-1}\right)$. The ratio between marketable yield and the total water received by the crop (irrigation + rainfall) was used to define the water use efficiency (WUE; $\mathrm{kg} \mathrm{m}^{-3}$ ).

Finally, on a sample of 10 marketable fruits from each plot, the following parameters were measured: equatorial and longitudinal diameter $(\mathrm{mm})$, soluble solids content of the flesh ( ${ }^{\circ}$ Brix), $\mathrm{pH}$ of tomato juice, titratable acidity (g citric acid $100 \mathrm{~mL}^{-1}$ fresh juice) [42] and dry matter content

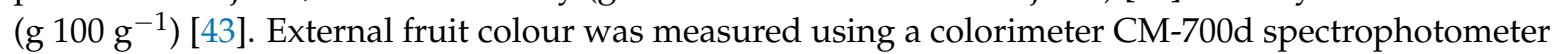
(Minolta Camera Co. Ltd., Osaka, Japan), with a D65 light source based on the CIELAB colour space represented by $L^{*}, a^{*}$, and $b^{*}$ values. Measurements were taken at four randomly selected areas of the fruit surface and mean values were used for analyses of $\mathrm{a}^{*} / \mathrm{b}^{*}$ ratio (colour index; $\mathrm{CI}$ ), which represents an index that sufficiently describes the colour changes of tomato fruit $[44,45]$.

\subsection{Statistical Analysis}

The datasets were tested according to the basic assumptions of analysis of variance (ANOVA). The normal distribution of the experimental error and the common variance of the experimental 
error were verified through Shapiro-Wilk and Bartlett's tests, respectively. When required, Box-Cox transformations [46] were applied prior to analysis. For all datasets, the ANOVA procedure was performed according to a split-plot design with three replicates. A three-way ANOVA procedure was performed considering the irrigation regime and the tomato cultivar as fixed factors and the growing seasons as random.

The statistical significance of the differences in the means was determined using Tukey's honest significance difference post hoc test at the $5 \%$ significance level. Bivariate statistical methods were applied to verify the significant correlations (Pearson's coefficients) among all parameters and to define the statistical relations (non-linear regression models), among CWSI and $g_{s}$ parameters.

Due to the correlations observed among the different parameters evaluated, these were jointly considered in a multivariate approach and were processed statistically for principal component analysis (PCA) [47]. Before performing the PCA, the values of each parameter were standardized. A factorial analysis was also performed on the PCA values, using the varimax method. All of the graphical representations were carried out using the SigmaPlot software (Systat Software, Inc., San Jose, CA, USA).

\section{Results and Discussion}

\subsection{Weather Conditions}

During the experimental period, the daily climatic parameters of rainfall, temperature, relative air humidity, and wind speed were recorded by a weather station near to the experimental area.

The two crop seasons were characterized by different rainfall and temperature trends, which influenced the duration of both vegetative and flowering periods (Figure 1 and Table 2).
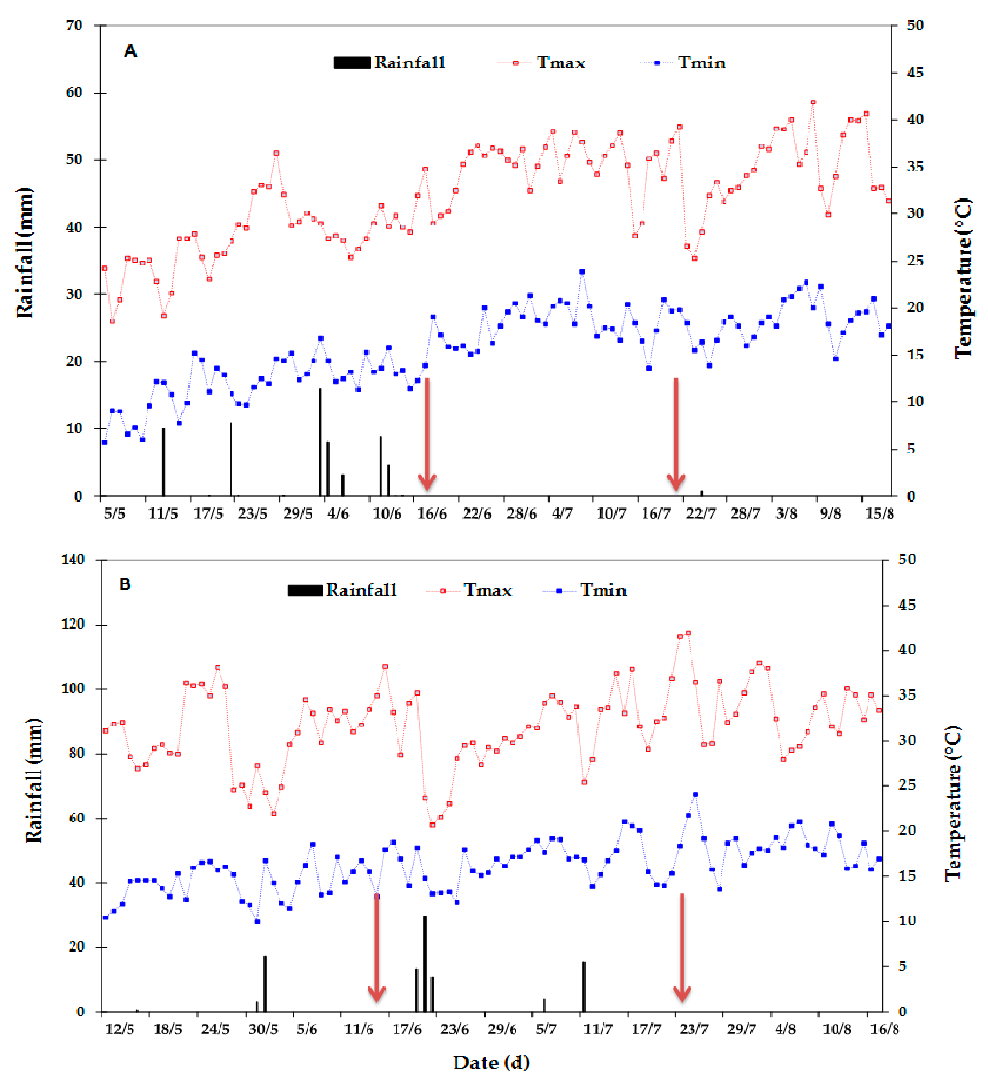

Figure 1. Rainfall, and maximum and minimum daily temperatures, recorded during the two processing tomato growing seasons $(\mathbf{A}) \mathrm{GS}_{1}$ and $(\mathbf{B}) \mathrm{GS}_{2}$. The arrows indicate the flowering of the first truss to fruit breaking colours of the first truss period. 
Table 2. Duration of phenological stages and related average and maximum temperature $\left(\mathrm{T}_{\max }\right)$, minimum temperature $\left(\mathrm{T}_{\min }\right)$ and rainfall.

\begin{tabular}{lcccccccc}
\hline \multirow{2}{*}{ Phenological Stages } & \multicolumn{2}{c}{ Days $(\mathbf{n})}$. & $\mathrm{T}_{\max }\left({ }^{\circ} \mathbf{C}\right)$ & $\mathrm{T}_{\min }\left({ }^{\circ} \mathbf{C}\right)$ & \multicolumn{2}{c}{ Rainfall (mm) } \\
\cline { 2 - 9 } & $\mathrm{GS}_{\mathbf{1}}$ & $\mathbf{G S}_{\mathbf{2}}$ & $\mathbf{G S}_{\mathbf{1}}$ & $\mathbf{G S}_{\mathbf{2}}$ & $\mathbf{G S}_{\mathbf{1}}$ & $\mathbf{G S}_{\mathbf{2}}$ & $\mathbf{G S}_{\mathbf{1}}$ & $\mathbf{G S}_{\mathbf{2}}$ \\
\hline From transplanting to flowering of the first truss & 49.0 & 37.0 & 27.9 & 31.0 & 12.4 & 14.9 & 62.7 & 21.5 \\
\hline $\begin{array}{l}\text { From flowering of the first truss to fruit breaking } \\
\text { colours of the first truss }\end{array}$ & 25.0 & 37.0 & 35.7 & 31.3 & 18.5 & 16.7 & 0.0 & 73.7 \\
\hline From fruit breaking colours of the first truss to harvest & 30.0 & 28.0 & 34.8 & 33.0 & 18.7 & 18.2 & 0.8 & 0.0 \\
\hline
\end{tabular}

$\mathrm{GS}_{1}$, first growing season (2008); $\mathrm{GS}_{2}$, second growing season (2009).

In $\mathrm{GS}_{1}$, the first period of the crop cycle (from transplanting to flowering of the first truss) was longer than in $\mathrm{GS}_{2}$, probably due to the higher rainfall and lower temperatures registered in $\mathrm{GS}_{1}$ compared with $\mathrm{GS}_{2}$. In contrast, during the flowering-fruit breaking colours, $\mathrm{GS}_{1}$ was characterized by higher temperature and no rainfall while, in $\mathrm{GS}_{2}$, approximately $74 \mathrm{~mm}$ fell. This period was shorter in the first growing season than in the second one. Finally, the temperature and rainfall trend of the third period (from fruit breaking colours of the first truss to harvest) was very similar for the two growing seasons. The different rainfall and temperature trends observed between the two growing seasons relative to the flowering-fruit breaking colours are very important, because this period is considered the most sensitive stage to water stress in tomato growth [41].

\subsection{Physiological, Quantitative, and Qualitative Parameters}

The stomatal conductance $\left(g_{s}\right)$ was significantly influenced only by the irrigation regime. Considering the mean of the three sampling dates, the highest value was observed for $\mathrm{IR}_{100}$ and the lowest for $\mathrm{IR}_{0}$, as expected (Figure 2A). The two-deficit irrigation regimes showed $g_{s}$ values significantly lower than $\mathrm{IR}_{100}$ as have been reported in several studies [1,34]. Moreover, the $\mathrm{IR}_{70 \mathrm{PRD}}$ showed lower values than $\mathrm{IR}_{70 \mathrm{DI}}$ (approximately $25 \%$ ), indicating that, under this regime, the plants closed the stomata more.

This result is partially in agreement with Tahi et al. [1] who, in a study on tomato grown under controlled conditions, reported $g_{s}$ values consistently lower in PRD and DI plants than in the control, whereas there was no clear difference between the two different deficit irrigation treatments. On the other hand, several authors reported, in other species, that the advantage of PRD over DI is that water uptake from the wet side of the root system maintains a favourable plant water status, while the roots of the dry side promote an increase in ABA production that decreases the $g_{s}$ [26].

CWSI is an index based on leaf temperature and associated with changes in crop water status [16]; it can vary between zero, indicating optimal crop water status, and one, indicating high crop water stress. Significant difference $(p \leq 0.05)$ in CWSI mean values was found between the two growing seasons ( 0.49 vs. 0.43 for $\mathrm{GS}_{1}$ and $\mathrm{GS}_{2}$, respectively). In the first year, which was characterized by no rainfall and higher temperatures during the flowering period, a higher CWSI value was recorded. Since the effect of the absence of rainfall on soil water availability was limited by the irrigation applied, the high air temperatures, as well as the absence of the refreshing effect of rains on leaf temperatures, seem to be the responsible for higher CWSI value of the $\mathrm{GS}_{1}$. Among the irrigation regimes, as expected, the highest CWSI value (approximately 0.8) was observed under $\mathrm{IR}_{0}$ and the lowest under $\mathrm{IR}_{100}$ (approximately 0.3) (Figure 2B). These values are in line with those obtained from Masseroni et al. [13] on spinach grown in pots in a greenhouse; who reported CWSI values between 0.2 and 0.4 for well-watered treatment, which increases up to approximately 0.9 for treatment without irrigation. CWSI under $I_{70 P R D}$ resulted significantly higher than under $I_{70 D}$, showing an opposite trend with respect to $g_{s}$. Between these two parameters, a logarithmic significant relationship was found (Figure 3). This result, obtained for tomato grown under open field conditions and subjected to deficit irrigation, is similar to that obtained by Yu et al. [16] who used Firmiana platanifolia (L.) grown 
in an incubator to develop a better understanding of the relationship between canopy temperature and stomatal conditions at various water stress levels.
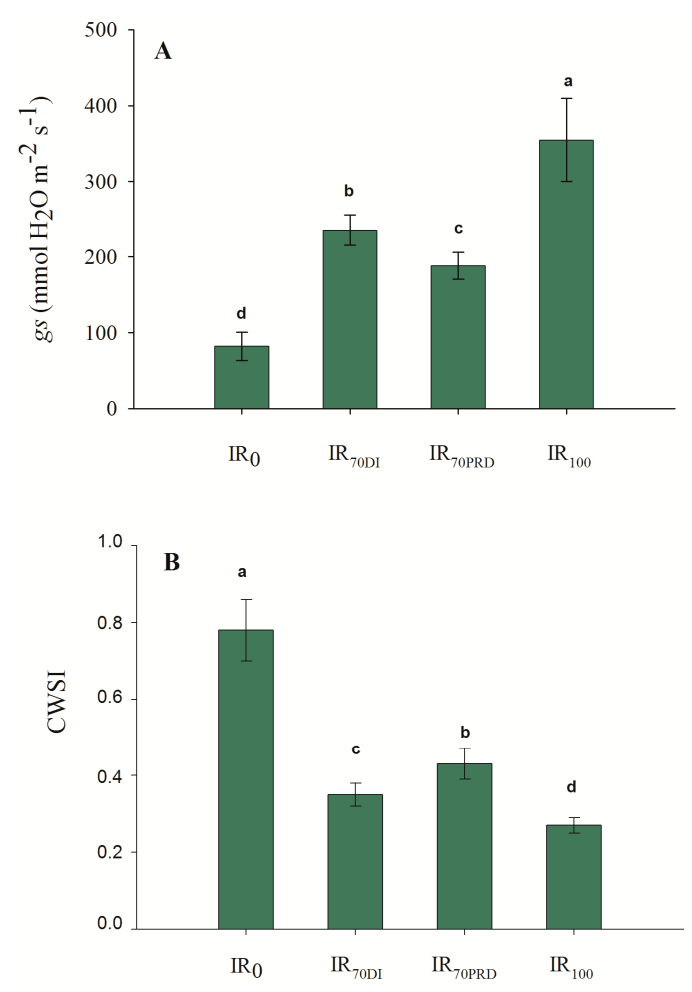

Figure 2. Effect of irrigation regime on stomatal conductance, $g_{s}(\mathbf{A})$ and crop water stress index, CWSI (B). IR $\mathrm{IR}_{100}$, full irrigation by restoring $100 \% \mathrm{ET}_{\mathrm{c}} ; \mathrm{IR}_{70 \mathrm{DI}}, 70 \%$ of the amount of water given to the $\mathrm{IR}_{100} \mathrm{~s} ; \mathrm{IR}_{70 \mathrm{PRD}}, 70 \%$ of the amount of water given to the $\mathrm{IR}_{100}$ applying partial root-zone drying; $\mathrm{IR}_{0}$, watering only at transplanting and during fertigation. Different letters $(a, b, c, d)$ indicate significantly different values at $p \leq 0.05$ according to Tukey test. The vertical bars indicate standard errors $(n=36$, 3 replicates $\times 2$ growing seasons $\times 2$ genotypes $\times 3$ sampling data).

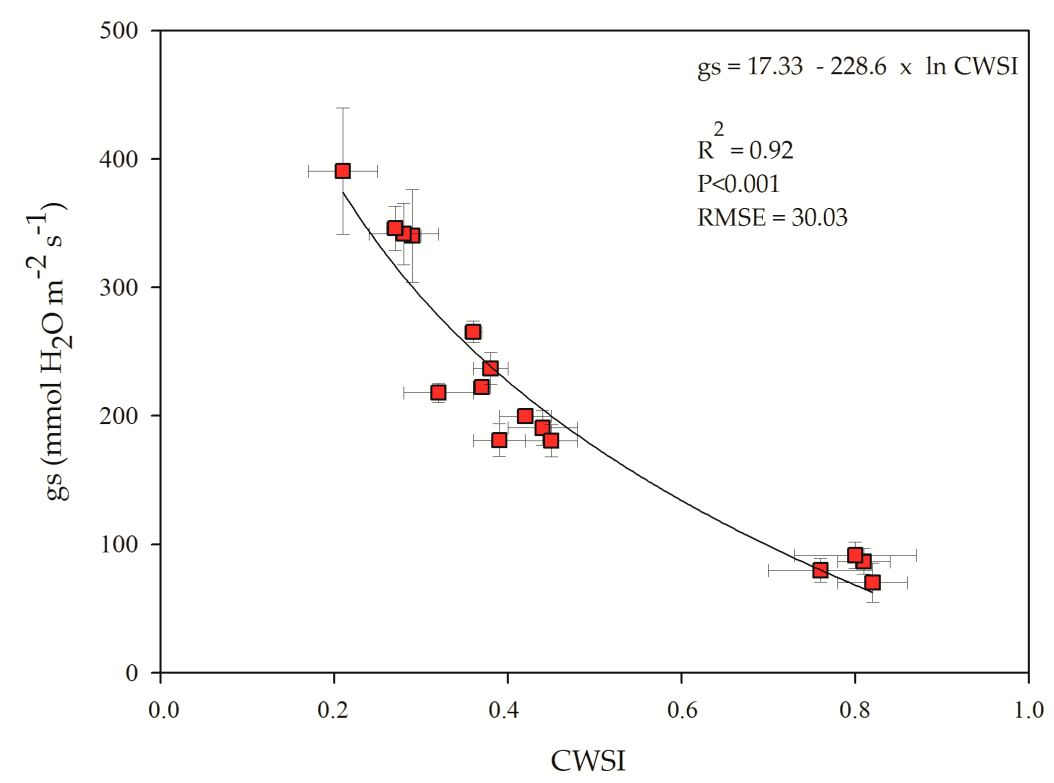

Figure 3. The relationship between the measured stomatal conductance $\left(g_{s}\right)$ and the calculated CWSI index. 
Despite the fact that the total yield was very similar in the two growing seasons, the marketable yield was significantly higher in $\mathrm{GS}_{2}$, which was characterized by higher rainfall and lower temperatures during the flowering period (Table 3). This was due to the higher number of discarded fruits in the first, more stressed year. On the other hand, as the CWSI value was also significantly lower in $\mathrm{GS}_{2}$, let us suppose a better plant water status. As for the cultivar, 'Ercole' showed higher values than 'Genius' for both total and marketable yield.

As for the irrigation regime, as expected, a significant yield decrease was observed with the decrease in the quantity of water supplied. However, although the two deficit regimes received approximately $24 \%$ less water than $\mathrm{IR}_{100}$, as a mean of the two growing seasons (Table 1 ), the yield reduction with relation to the optimum regime was equal to $16.2 \%$ under $I R_{70 \mathrm{DI}}$ and only $7.6 \%$ under $\mathrm{IR}_{70 \mathrm{PRD}}$. The marketable yield obtained under $\mathrm{IR}_{70 \mathrm{PRD}}$, indeed, was significantly higher than under $\mathrm{IR}_{70 \mathrm{DI}}$, despite the two regimes receiving the same water amount.

This result shows that the PRD treatments had higher yield benefits compared with conventional DI practice, as reported also by Sepaskhah and Ahmadi [26]. Similar results were found in relation to total yield (Table 3). On the other hand, under the $\mathrm{IR}_{70 \mathrm{PRD}}$ regime, fruits reached a larger size compared to $\mathrm{IR}_{70 \mathrm{DI}}$ in terms of both longitudinal and equatorial diameters (Table 3 ), and these fruits were not different from the $\mathrm{IR}_{100}$ value for the longitudinal diameter; moreover, $\mathrm{IR}_{70 \mathrm{PRD}}$ showed values significantly higher than $\mathrm{IR}_{100}$ with respect to fruit equatorial diameter. These two morphological parameters, indeed, resulted in being positively and highly correlated with the marketable yield ( $r=-0.52$ and 0.76 for longitudinal and equatorial diameters, respectively; $p<0.001)$. This result is in agreement with Affi et al. [48] that showed, in a study on tomato grown under controlled conditions, similar longitudinal diameter $(77-82 \mathrm{~mm})$ between the well-watered and the 70 PRD regimes. On the other hand, the significantly lower values observed for $\mathrm{IR}_{70 \mathrm{DI}}$ and $\mathrm{IR}_{0}$ can be explained by water and nutrient shortages, as also reported by Zegbe-Domínguez et al. [49]. Moreover, the growing season influenced the fruit size, since the fruit's longitudinal diameter was significantly lower in the first year, which was characterized by lower rainfall and higher temperatures.

The WUE values were similar in the two growing seasons for all the water regimes applied, with the exception of $\mathrm{IR}_{0}$, which showed significantly higher values in the first growing season, which was characterized by lower rainfall and higher temperature (Figure 4 and Table 2). Moreover, between the two water deficit regimes, only the IR $\mathrm{R}_{70 \mathrm{PRD}}$ showed values significantly higher with respect to $\mathrm{IR}_{100}$ in both years. This result is partially in agreement with those reported in Sepaskhah et al. [26] about the not significant difference between water use efficiencies in PRD and DI. Our results also have to be interpreted considering the different $g_{s}$ values that we obtained for the two deficit irrigation techniques, which were lower under IR $\mathrm{IR}_{70 \mathrm{PRD}}$ than under IR $\mathrm{IR}_{70 \mathrm{DI}}$ (Figure $2 \mathrm{~A}$ ). WUE and $g_{s}$, in fact, were highly and negatively correlated $(r=-0.68 ; p<0.001)$. The lower $g_{s}$ values and the higher marketable yield showed by $\mathrm{IR}_{70 \mathrm{PRD}}$ compared to $\mathrm{IR}_{70 \mathrm{DI}}$ allowed us to suppose that the stomata closing under the PRD regime do not significantly affect the photosynthesis rate, resulting in the WUE increase. Studies on tomatoes grown in greenhouses [50,51] have shown that photosynthesis under the PRD condition is not reduced compared to fully-irrigated plants. In our experimental conditions, which were open field conditions, the PRD determined a decrease in $g_{s}$ values and an increase in marketable yield, and WUE let us suppose that there was no limiting in photosynthesis rate.

The different improvement of WUE observed under PRD and DI regimes with respect to $\mathrm{IR}_{100}$ means that the irrigation methods, as well as the irrigation volume, is important in determining crop growth. 
Table 3. Effect of growing season, tomato cultivar, and irrigation regime experimental factors on main morphological quantitative and qualitative traits. The data shown are the means \pm standard errors $(n=24)$ for each parameter.

\begin{tabular}{|c|c|c|c|c|c|c|c|c|}
\hline \multirow{3}{*}{ Parameters } & \multicolumn{8}{|c|}{ Experimental Factors } \\
\hline & \multicolumn{2}{|c|}{ Growing Season ${ }^{1}$} & \multicolumn{2}{|c|}{ Genotype } & \multicolumn{4}{|c|}{ Irrigation Regime $^{2}$} \\
\hline & $\mathrm{GS}_{1}$ & $\mathrm{GS}_{2}$ & Genius & Ercole & $\mathbf{I R}_{\mathbf{0}}$ & $\mathrm{IR}_{70 \mathrm{DI}}$ & $\mathrm{IR}_{70 \mathrm{PRD}}$ & $\mathrm{IR}_{100}$ \\
\hline \multicolumn{9}{|l|}{ Quantitative parameters } \\
\hline Marketable yield $\left(\mathrm{t} \mathrm{ha}^{-1}\right)$ & $53.31 \pm 1.61^{\mathbf{b}}$ & $55.11 \pm 1.5^{\mathrm{a}}$ & $52.3 \pm 3.30^{\mathbf{b}}$ & $56.2 \pm 3.30^{\mathrm{a}}$ & $24.7 \pm 1.48^{\mathrm{d}}$ & $59.3 \pm 1.15^{c}$ & $64.1 \pm 0.80^{\mathbf{b}}$ & $68.9 \pm 1.06^{\mathrm{a}}$ \\
\hline Total yield $\left(\mathrm{tha}^{-1}\right)$ & $59.1 \pm 2.11^{\mathrm{a}}$ & $60.0 \pm 2.30^{a}$ & $56.9 \pm 3.35^{b}$ & $62.1 \pm 4.05^{\mathrm{a}}$ & $30.1 \pm 1.62^{\mathrm{d}}$ & $63.1 \pm 1.52^{c}$ & $67.1 \pm 1.33^{b}$ & $77.9 \pm 1.32^{\mathrm{a}}$ \\
\hline \multicolumn{9}{|l|}{ Morphometric parameters } \\
\hline Fruit longitudinal diameter $(\mathrm{mm})$ & $70.50 \pm 2.70^{\mathbf{b}}$ & $77.24 \pm 3.21^{\mathrm{a}}$ & $73.63 \pm 1.01^{\mathrm{a}}$ & $74.16 \pm 1.20^{\mathrm{a}}$ & $69.6 \pm 1.32^{\mathrm{c}}$ & $72.71 \pm 1.18^{\mathbf{b}}$ & $75.80 \pm 1.32^{\mathrm{a}}$ & $77.47 \pm 1.48^{\mathrm{a}}$ \\
\hline Fruit equatorial diameter $(\mathrm{mm})$ & $34.93 \pm 0.50^{\mathrm{a}}$ & $34.85 \pm 0.61^{a}$ & $34.39 \pm 0.60^{\mathrm{a}}$ & $35.39 \pm 0.32^{\mathbf{a}}$ & $31.43 \pm 0.38^{c}$ & $35.40 \pm 0.51^{\mathbf{b}}$ & $37.10 \pm 0.32^{\mathrm{a}}$ & $35.63 \pm 0.35^{a, b}$ \\
\hline \multicolumn{9}{|l|}{ Qualit ative parameters } \\
\hline $\begin{array}{l}\text { Dry matter of fruits } \\
\left(\mathrm{g} 100 \mathrm{~g}^{-1} \text { fresh }\right.\end{array}$ & $5.43 \pm 0.13^{\mathrm{a}}$ & $5.60 \pm 0.16^{\mathrm{a}}$ & $5.39 \pm 0.10^{\mathrm{a}}$ & $5.63 \pm 0.13^{\mathrm{a}}$ & $5.80 \pm 0.15^{\mathrm{a}}$ & $5.83 \pm 0.28^{\mathrm{a}}$ & $5.25 \pm 0.18^{\mathrm{a}}$ & $5.16 \pm 0.07^{\mathrm{a}}$ \\
\hline $\mathrm{pH}$ & $4.30 \pm 0.04^{\mathrm{a}}$ & $4.45 \pm 0.05^{\mathrm{a}}$ & $4.40 \pm 0.04^{\mathrm{a}}$ & $4.37 \pm 0.05^{\mathbf{a}}$ & $4.46 \pm 0.04^{\mathrm{a}}$ & $4.29 \pm 0.07^{\mathrm{a}}$ & $4.39 \pm 0.05^{\mathrm{a}}$ & $4.38 \pm 0.06^{\mathrm{a}}$ \\
\hline $\begin{array}{l}\text { Tritable acidity } \\
\text { (g citric acid } 100 \mathrm{~mL}^{-1} \text { fresh juice) }\end{array}$ & $0.34 \pm 0.02^{\mathrm{a}}$ & $0.34 \pm 0.01^{\mathbf{a}}$ & $0.35 \pm 0.05^{\mathbf{a}}$ & $0.34 \pm 0.05^{\mathbf{a}}$ & $0.31 \pm 0.01^{\mathbf{b}}$ & $0.38 \pm 0.01^{\mathbf{a}}$ & $0.33 \pm 0.16^{\mathbf{b}}$ & $0.35 \pm 0.11^{\mathbf{a}, \mathbf{b}}$ \\
\hline Soluble solids content $\left({ }^{\circ}\right.$ Brix $)$ & $6.17 \pm 0.11^{\mathbf{a}}$ & $6.28 \pm 0.15^{a}$ & $6.19 \pm 0.12^{\mathbf{a}}$ & $6.28 \pm 0.14^{\mathrm{a}}$ & $6.78 \pm 0.12^{\mathbf{a}}$ & $6.15 \pm 0.17^{\mathrm{c}}$ & $6.37 \pm 0.15^{\mathbf{a}, \mathbf{b}}$ & $5.57 \pm 0.10^{c}$ \\
\hline Colour index & $1.05 \pm 0.09 \mathbf{b}$ & $1.12 \pm 0.1^{\mathbf{b}}$ & $1.11 \pm 0.06^{\mathrm{a}}$ & $1.06 \pm 0.05^{\mathrm{a}}$ & $1.10 \pm 0.01^{\mathbf{a}}$ & $1.12 \pm 0.02^{\mathrm{a}}$ & $1.07 \pm 0.02^{\mathbf{b}}$ & $1.06 \pm 0.01^{\mathbf{b}}$ \\
\hline
\end{tabular}

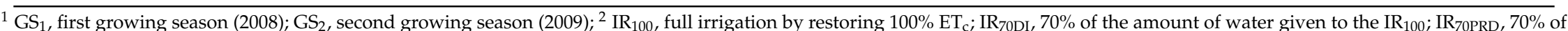
the amount of water given to the $\mathrm{IR}_{100}$ applying partial root-zone drying; $I R_{0}$, watering only at transplanting and during fertigation. For each row and experimental factor, different letters $(\mathrm{a}, \mathrm{b}, \mathrm{c}, \mathrm{d})$ indicate significantly different values at $p \leq 0.05$ according to Tukey's test. 


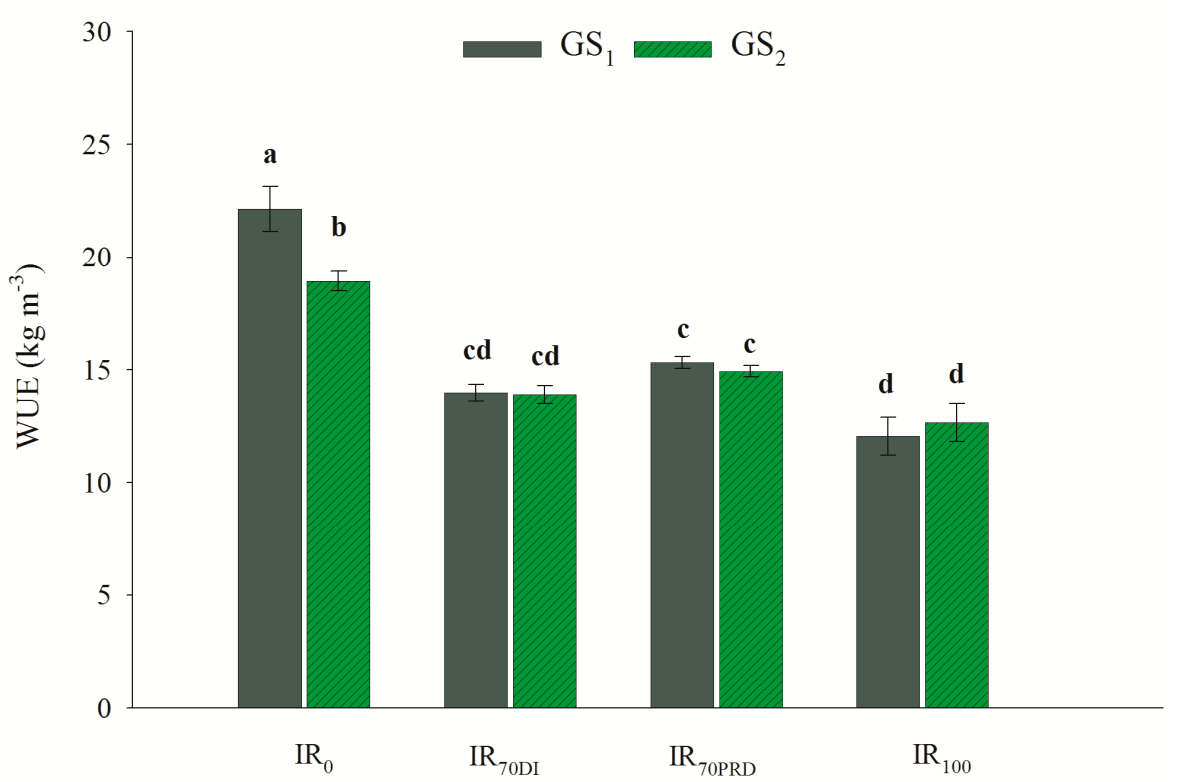

Figure 4. Effect of the interaction irrigation regime $\times$ growing season on water use efficiency (WUE). $\mathrm{IR}_{100}$, full irrigation by restoring $100 \% \mathrm{ET}_{\mathrm{c}} ; \mathrm{IR}_{70 \mathrm{DI}}, 70 \%$ of the amount of water given to the $\mathrm{IR}_{100}$; $\mathrm{IR}_{70 \mathrm{PRD}}, 70 \%$ of the amount of water given to the $\mathrm{IR}_{100}$ applying partial root-zone drying; $\mathrm{IR}_{0}$, watering only at transplanting and during fertigation. $\mathrm{GS}_{1}$, first growing season (2008); $\mathrm{GS}_{2}$, second growing season (2009). Different letters (a, b, c, d) indicate significantly different values at $p \leq 0.05$ according to a Tukey test. The vertical bars indicate standard errors ( $n=12,3$ replicates $\times 2$ growing seasons $\times 2$ genotype).

This result may contrast with our previous study [35], in which only one year was evaluated, demonstrating the relevant effect of the year on the application of the PRD technique. In fact, the WUE increment showed by $\mathrm{IR}_{70 \mathrm{PRD}}$ with respect to $\mathrm{IR}_{100}$ was equal to $27 \%$ in the first growing season and of $17 \%$ in the second one, showing that the positive effect of PRD on the WUE is more evident in the more stressed year.

The higher increase of WUE under PRD with respect to $\mathrm{IR}_{100}$ obtained in the stressed year is of particular interest in view of climate change-related issues. The frequency and severity of prolonged periods of heat and drought stress, in fact, is expected to increase in the future in semi-arid Mediterranean areas [2,3]. Moreover, as reported by Expósito and Berbel [52], the extensive adoption of deficit irrigation techniques could have great consequence at basin or aquifer levels, requiring further research.

The effect of the irrigation regime was significant for all the qualitative traits with the exception of the $\mathrm{pH}$. The highest titratable acidity value was obtained under the $\mathrm{IR}_{70 \mathrm{DI}}$ regime and the lowest under $\mathrm{IR}_{0}$. For the soluble solids, the highest value was obtained, as expected, by the $\mathrm{IR}_{0}$ regime; however, the $I_{70 P R D}$ regime showed values significantly higher than $I_{100}$ and $I_{70 D I}$. Additionally, Haghighi et al. [32] found soluble solids fruit content significantly higher in PRD fruit than in the well-watered plants. Previous reports have confirmed higher soluble solid values in tomato fruit grown under PRD [49,50]. However, Campos et al. [51] found no difference in soluble solids values between PRD and control fruits. It is presumed that the higher soluble solids values were due to higher rates of conversion of starch into sugars [53] and lower fruit water contents under water deficit [54]. The CI, which represents an index that sufficiently describes the colour changes of tomato fruit, showed higher values under $\mathrm{IR}_{70 \mathrm{DI}}$ and $\mathrm{IR}_{0}$ regimes, while no differences were found between $\mathrm{IR}_{100}$ and $\mathrm{IR}_{70 \mathrm{PRD}}$. Consistent with these findings, other authors reported that deficit-irrigated tomato fruits had higher colour intensity than fully-irrigated fruits $[32,49,55,56]$. However, the result obtained with PRD irrigation was in agreement with Bogale et al. [56] relative to tomato cultivar 'Matina', but not with Haghighi et al. [32] who reported a redder colour of PRD fruits with respect to the well-watered 
ones. The authors suggested that the stronger red colour might be a result of a higher rate of ethylene production [32,57] observed in fruits produced under DI and PRD, in which ethylene may have some positive effect on the development of lycopene content in tomatoes [58]. In our experimental condition, this was true for $\mathrm{IR}_{70 \mathrm{DI}}$, but not for $\mathrm{IR}_{70 \mathrm{PRD}}$.

\subsection{Principal Component Analysis on the Quali-Quantitative Composition of the Tomato Fruit}

According to the PCA analysis, the twelve original variables related to physiological, quantitative and qualitative aspects were reduced to two principal components, which represent $75.6 \%$ of the total variability. In particular, the first component $\left(\mathrm{PC}_{1}\right)$ accounted for the $52.9 \%$ of the total variability, while the second component $\left(\mathrm{PC}_{2}\right)$ accounted for the $22.7 \%$ (Table 4 ).

Table 4. Standardized coefficients (scores) and Pearson's correlation coefficient values for the first two principal components $\left(\mathrm{PC}_{1-2}\right)$, considering the original variables. The corresponding percentages of accounted variation are also reported.

\begin{tabular}{|c|c|c|c|c|}
\hline \multirow{2}{*}{ Original Variables } & \multicolumn{2}{|c|}{ Standardized Coefficients (Scores) } & \multicolumn{2}{|c|}{ Pearson's Correlation Coefficients } \\
\hline & $\mathrm{PC}_{1}$ & $\mathrm{PC}_{2}$ & $\mathrm{PC}_{1}$ & $\mathrm{PC}_{2}$ \\
\hline Marketable yield & 0.92 & -0.27 & $0.90^{* * *}$ & $-0.25^{\mathrm{ns}}$ \\
\hline Total yield & 0.93 & -0.28 & $0.91 * * *$ & $-0.27^{\mathrm{ns}}$ \\
\hline Water use efficiency & -0.79 & 0.08 & $-0.75^{* * *}$ & $0.04^{\mathrm{ns}}$ \\
\hline Fruit longitudinal diameter & 0.63 & 0.07 & $0.60 * *$ & $0.06^{\mathrm{ns}}$ \\
\hline Fruit equatorial diameter & 0.76 & -0.15 & $0.74 * * *$ & $-0.15^{\mathrm{ns}}$ \\
\hline $\mathrm{pH}$ of the flesh & -0.01 & 0.90 & $-0.02^{\mathrm{ns}}$ & $0.92 * * *$ \\
\hline Dry matter of fruit & -0.27 & 0.34 & $-0.26^{\mathrm{ns}}$ & $0.33 *$ \\
\hline Titratable acidity & 0.10 & -0.83 & $0.09^{\mathrm{ns}}$ & $-0.81 * * *$ \\
\hline Soluble solids content & -0.63 & 0.24 & $-0.65^{* *}$ & $0.24^{\mathrm{ns}}$ \\
\hline Colour index & -0.16 & 0.30 & $-0.16^{\mathrm{ns}}$ & $0.31 *$ \\
\hline Crop water stress index & -0.91 & 0.30 & $-0.90 * * *$ & $0.27^{\mathrm{ns}, *}$ \\
\hline Stomatal conductance & 0.84 & -0.26 & $0.85^{* * *}$ & $-0.24^{\mathrm{ns}}$ \\
\hline Percentage explained variation & 52.9 & 22.7 & & \\
\hline Percentage cumulative variation & 75.6 & & & \\
\hline
\end{tabular}

To correctly interpret the relationship between the two components and the original variables, it is important to recall that $\mathrm{PC}_{1}$ and $\mathrm{PC}_{2}$ are linear combinations of the original variables and standardized coefficients (scores), which maximize the discrimination among the detected components. The original variable with the largest standardized coefficient has, indeed, the strongest impact on the selected components. The results of PCA analysis showed that the $\mathrm{PC}_{1}$ was mainly and positively associated with total yield, marketable yield, equatorial and longitudinal diameters, and negatively with CWSI, WUE, and soluble solids content (Table 4). The $\mathrm{PC}_{2}$ was mainly and positively related to $\mathrm{pH}$, fruit dry matter, and colour index, and negatively related to titratable acidity. Thus, $\mathrm{PC}_{1}$ can be considered as a "physio-quantitative" component and $\mathrm{PC}_{2}$ as a "qualitative component".

By means of PCA analysis, genetic differences between the two cultivars under study were more evident across the irrigation regimes and the two growing seasons, especially for the qualitative component. Indeed, a sharp separation between the two cultivars was clearly evident on $\mathrm{PC}_{2}$ for $\mathrm{IR}_{0}$ and $\mathrm{IR}_{100}$, with 'Genius' showing the best performance in $\mathrm{IR}_{0}$ in the second growing season, and the worst in $\mathrm{IR}_{100}$ in the first growing season (Figure 5). Thus, 'Genius' showed better qualitative performance when grown under extreme water stress conditions, losing this ability when fully irrigated. The opposite was true for 'Ercole'. Under the two deficit irrigation regimes, the two cultivars showed the same qualitative performance in the two growing seasons, and the separation along $\mathrm{PC}_{2}$ only showed a better result of PRD compared with DI. 


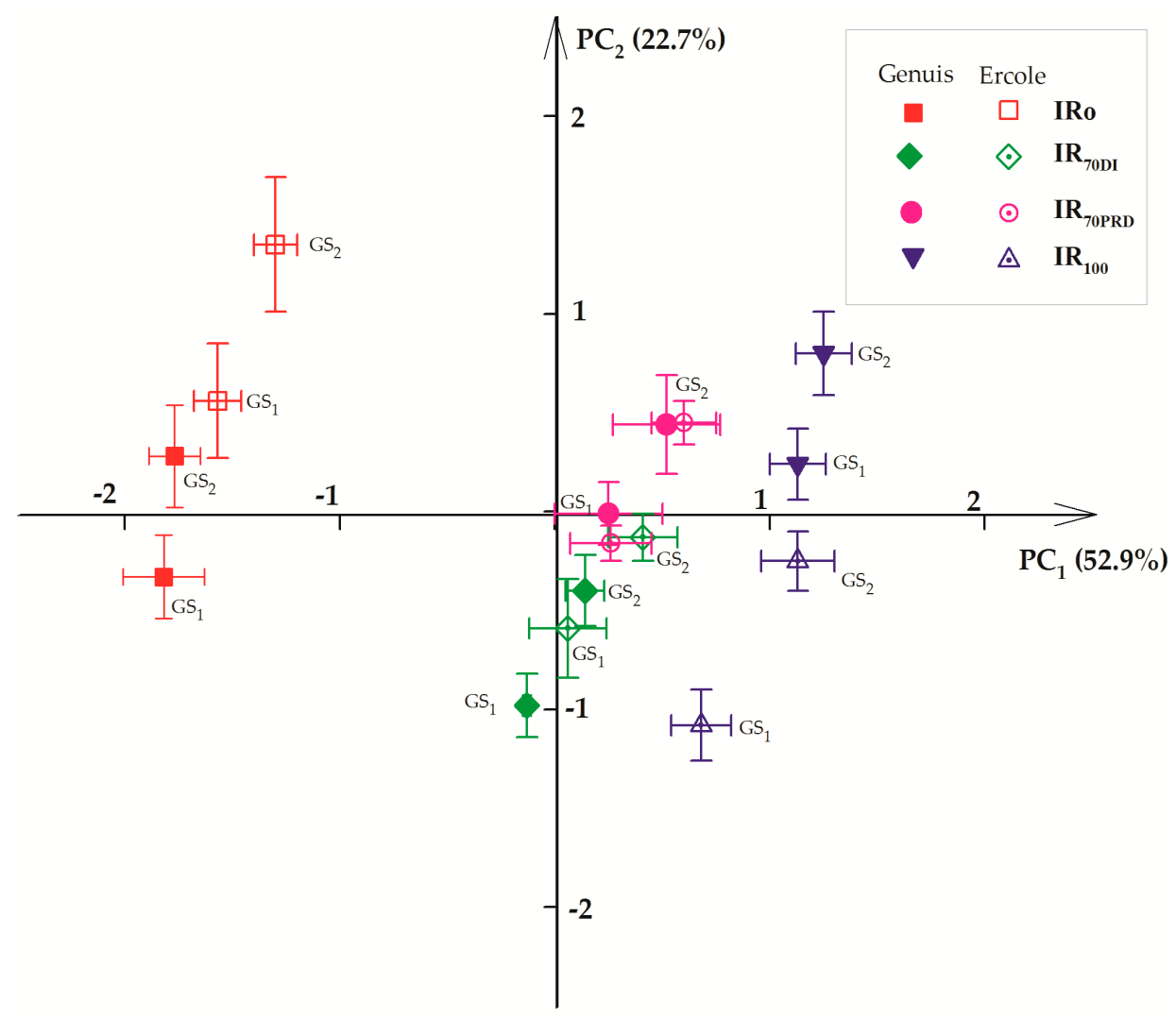

Figure 5. Biplot relative to the principal component analysis performed on all parameters. $\mathrm{IR}_{100}$, full irrigation by restoring $100 \% \mathrm{ET}_{\mathrm{c}} ; \mathrm{IR}_{70 \mathrm{DI}}, 70 \%$ of the amount of water given to the $\mathrm{IR}_{100} ; \mathrm{IR}_{70 \mathrm{PRD}}$, $70 \%$ of the amount of water given to the $\mathrm{IR}_{100}$ applying partial root-zone drying; $\mathrm{IR}_{0}$, watering only at transplanting and during fertigation. $\mathrm{GS}_{1}$, first growing season (2008); $\mathrm{GS}_{2}$, second growing season (2009); horizontal and vertical bars indicate standard errors ( $n=3$ replicates).

\section{Conclusions}

In the present study, we evaluated the effects of PRD and DI on physiological, quantitative, and qualitative parameters in processing tomatoes grown in open field conditions in a Mediterranean climate under two growing seasons. The first year was characterized by no rainfall and higher temperature during the flowering period as compared to the second one. Our results confirm the lower $g_{s}$ values of PRD with respect to DI techniques (approximately 25\%), indicating that, in open field conditions and under different climate trends, using PRD, the plants closed the stomata more. Despite this finding, under $\mathrm{IR}_{70 \mathrm{PRD}}, \mathrm{CWSI}$ was significantly higher than under $\mathrm{IR}_{70 \mathrm{DI}}$, and the marketable yield obtained was significantly higher; although the two deficit regimes received approximately $24 \%$ less water than $\mathrm{IR}_{100}$, the yield reduction was equal to $16.2 \%$ under $\mathrm{IR}_{70 \mathrm{DI}}$, and only $7.6 \%$ under $\mathrm{IR}_{70 \mathrm{PRD}}$.

The WUE increment showed by $I_{70 P R D}$ with respect to $I_{100}$ was equal to $27 \%$ in the first growing season and was $17 \%$ in the second one, showing that the positive effect of PRD on the WUE is more evident in the more stressed year. Finally, the results from the PCA showed that the two cultivars differed in their qualitative response in the two extreme regimes ( $\mathrm{IR}_{100}$ and $\left.\mathrm{IR}_{0}\right)$, but not under PRD and DI regimes. Moreover, the PRD showed higher values along the quality factor compared with DI. Under PRD, the higher quality performance, as well as the higher WUE obtained with respect to $I_{100}$, especially in the more stressed year, are of particular interest in view of climate change-related issues, such as prolonged periods of heat and drought stress, which are predicted to increase in frequency and severity in semi-arid Mediterranean areas. 
Acknowledgments: This study was carried out as part of the Project 'Tecniche di risparmio idrico nella coltivazione del pomodoro da industria', co-funded by the Italian Ministry of Agriculture, within the Italian OIGA Programme.

Author Contributions: Marcella Michela Giuliani has contributed in developing the research ideas, conducting the research, analyzing the data, and writing the manuscript. Eugenio Nardella provided efforts on field research, lab analysis and manuscript writing. Anna Gagliardi provided efforts on lab analysis and manuscript writing. Giuseppe Gatta has contributed in developing the research ideas, conducting the research, analyzing the data, and writing the manuscript. All authors read and approved the final manuscript.

Conflicts of Interest: The authors declare no conflict of interest.

\section{References}

1. Tahi, H.; Wahbi, S.; Wakrim, R.; Aganchich, B.; Serraj, R.; Centritto, M. Water relations, photosynthesis, growth, and water use efficiency in tomato plants subjected to partial rootzone drying and regulated deficit irrigation. Plant Biosyst. 2007, 141, 265-274. [CrossRef]

2. Lovelli, S.; Perniola, M.; Scalcione, E.; Troccoli, A.; Ziska, L.H. Future climate change in the Mediterranean area: Implications for water use and weed management. Ital. J. Agron. 2012, 7, 44-49. [CrossRef]

3. Ventrella, D.; Giglio, L.; Charfeddine, M.; Lopez, R.; Castellini, M.; Sollitto, D.; Castrignanò, A.; Fornaro, F. Climate change impact on crop rotations of winter durum wheat and tomato in Southern Italy: Yield analysis and soil fertility. Ital. J. Agron. 2012, 7, 100-108. [CrossRef]

4. Ferrarin, C.; Zaggia, L.; Paschini, E.; Scirocco, T.; Lorenzetti, G.; Bajo, M.; Penna, P.; Francavilla, M.; D'Adamo, R.; Guerzoni, S. Hydrological regime and renewal capacity of the micro-tidal Lesina Lagoon, Italy. Estuar. Coast. 2014, 37, 79-93. [CrossRef]

5. Gatta, G.; Libutti, A.; Beneduce, L.; Gagliardi, A.; Disciglio, G.; Lonigro, A.; Tarantino, E. Reuse of treated municipal wastewater for globe artichoke irrigation: Assessment of effects on morpho-quantitative parameters and microbial safety of yield. Sci. Hortic. 2016, 213, 55-65. [CrossRef]

6. Giuliani, M.M.; Gatta, G.; Nardella, E.; Tarantino, E. Water saving strategies assessment on processing tomato cultivated in Mediterranean region. Ital. J. Agron. 2016, 11, 69-76. [CrossRef]

7. Costa, J.M.; Ortuño, M.F.; Chaves, M.M. Deficit irrigation as a strategy to save water: Physiology and potential application to horticulture. J. Integr. Plant Biol. 2007, 49, 1421-1434. [CrossRef]

8. Kirda, C.; Cetin, M.; Dasgan, Y.; Topcu, S.; Kaman, H.; Ekici, B.; Derici, M.R.; Ozguven, A.I. Yield response of greenhouse grown tomato to partial root drying and conventional deficit irrigation. Agric. Water Manag. 2004, 69, 191-201. [CrossRef]

9. Cantore, V.; Lechkar, O.; Karabulut, E.; Sellami, M.H.; Albrizio, R.; Boari, F.; Stellacci, A.M.; Todorovic, M. Combined effect of deficit irrigation and strobilurin application on yield, fruit quality and water use efficiency of "cherry" tomato (Solanum lycopersicum L.). Agric. Water Manag. 2016, 167, 53-61. [CrossRef]

10. English, M.J.; Raja, S.N. Perspectives on deficit irrigation. Agric. Water Manag. 1996, 32, 1-14. [CrossRef]

11. Zegbe, J.A.; Behbouidan, M.H.; Clothier, B.E. Responses of 'Petopride' processing tomato to partial rootzone drying at different phenological stages. Irrig. Sci. 2006, 24, 203-210. [CrossRef]

12. Ahmadi, S.H.; Andersen, M.N.; Plauborg, F.; Poulsen, R.T.; Jensen, C.R.; Sepaskhah, A.R.; Hansen, S. Effects of irrigation strategies and soils on field grown potatoes: Gas exchange and xylem [ABA]. Agric. Water Manag. 2010, 97, 1486-1494. [CrossRef]

13. Masseroni, D.; Uddin, J.; Tyrrell, R.; Mareels, I.; Gandolfi, C.; Facchi, A. Towards a smart automated surface irrigation management in rice-growing areas in Italy. J. Agric. Eng. 2017, 48, 42-48. [CrossRef]

14. Idso, S.B.; Jackson, R.D.; Pinter, P.J.; Hatfield, J. Normalizing the stress-degree-day parameter for environmental variability. Agric. Meteorol. 1981, 24, 45-55. [CrossRef]

15. Pou, A.; Diago, M.P.; Medrano, H.; Baluja, J.; Tardaguila, J. Validation of thermal indices for water status identification in grapevine. Agric. Water Manag. 2014, 134, 60-72. [CrossRef]

16. Yu, M.H.; Ding, G.D.; Gao, G.L.; Zhao, Y.Y.; Sai, L.Y.K. Using plant temperature to evaluate the response of stomatal conductance to soil moisture deficit. Forests 2015, 6, 3748-3762. [CrossRef]

17. Gowing, D.J.; Davies, W.J.; Jones, H.G. A positive root-sourced signal as an indicator of soil drying in apple, Malus $x$ domestica Borkh. J. Exp. Bot. 1990, 41, 1535-1540. [CrossRef]

18. Turner, D.W.; Menzel, C.M.; Simpson, D.R. Short term drying of half the root system reduces growth but not water status or photosynthesis in leaves of passionfruit (Passiflora sp.). Sci. Hortic. 1996, 65, 25-36. [CrossRef] 
19. Stoll, M.; Loveys, B.R.; Dry, P.R. Hormonal changes induced by partial rootzone of irrigated grapevine. J. Exp. Bot. 2000, 51, 1627-1634. [CrossRef] [PubMed]

20. Dos Santos, T.P.; Lopes, C.M.; Rodrigues, M.L.; de Souza, C.R.; Maroco, J.P.; Pereira, J.S.; Silva, J.R.; Chaves, M.M. Partial rootzone drying: Effects on growth and fruit quality of field-grown grapevines (Vitis vinifera). Funct. Plant Biol. 2003, 30, 663-671. [CrossRef]

21. De Souza, C.R.; Maroco, J.P.; dos Santos, T.P.; Rodrigues, M.L.; Lopes, C.; Pereira, J.S.; Chaves, M.M. Control of stomatal aperture and carbon uptake by deficit irrigation in two grapevine cultivars. Agric. Ecosyst. Environ. 2005, 106, 261-274. [CrossRef]

22. Fort, C.; Fauveau, M.L.; Muller, F.; Label, P.; Granier, A.; Dreyer, E. Stomatal conductance, growth and root signalling in young oak seedlings subjected to partial soil drying. Tree Physiol. 1997, 17, 281-289. [CrossRef] [PubMed]

23. Fort, C.; Muller, F.; Label, P.; Granier, A.; Dreyer, E. Stomatal conductance, growth and root signalling in Betula pendula seedlings subjected to partial soil drying. Tree Physiol. 1998, 18, 769-776. [CrossRef] [PubMed]

24. Wahbi, S.; Wakrim, R.; Aganchich, B.; Tahi, H.; Serraj, R. Effects of partial rootzone drying (PRD) on adult olive tree (Olea europaea) in field conditions under arid climate. I. Physiological and agronomic responses. Agric. Ecosyst. Environ. 2005, 106, 289-301. [CrossRef]

25. Centritto, M.; Wahbi, S.; Serraj, R.; Chaves, M.M. Effects of partial rootzone drying (PRD) on adult olive tree (Olea europaea) in field conditions under arid climate. II. Photosynthetic responses. Agric. Ecosyst. Environ. 2005, 106, 303-311. [CrossRef]

26. Sepaskhah, A.R.; Ahmadi, S.H. A review on partial root-zone drying irrigation. Int. J. Plant Prod. 2010, 4, 241-258. [CrossRef]

27. Davies, W.J.; Bacon, M.A.; Stuart Thompson, D.; Sobeih, W.; González Rodríguez, L. Regulation of leaf and fruit growth in plants growing in drying soil: Exploitating of the plants' chimica signalling system and hydraulic architecture to increase the efficiency of water use in agricolture. J. Exp. Bot. 2000, 51, 1617-1626. [CrossRef] [PubMed]

28. Mingo, D.M.; Bacon, M.A.; Davies, W.J. Non-hydraulic regulation of fruit growth in tomato plants (Lycopersicon esculentum cv. Solairo) growing in drying soil. J. Exp. Bot. 2003, 54, 1205-1212. [CrossRef] [PubMed]

29. Sobeih, W.Y.; Dodd, I.C.; Bacon, M.A.; Grierson, D.; Davies, W.J. Long-distance signals regulating stomatal conductance and leaf growth in tomato (Lycopersicon esculentum) plants subjected to partial root-zone drying. J. Exp. Bot. 2004, 55, 2353-2363. [CrossRef] [PubMed]

30. Topcu, S.; Kirda, C.; Dasgan, Y.; Kaman, H.; Cetin, M.; Yazici, A.; Bacon, M.A. Yield response and N fertiliser recovery of tomato grown under deficit irrigation. Eur. J. Agron. 2007, 26, 64-70. [CrossRef]

31. Kirda, C.; Topcu, S.; Cetin, M.; Dasgan, H.Y.; Kaman, H.; Topaloglu, F.; Derici, M.R.; Ekici, B. Prospects of partial root zone irrigation for increasing irrigation water use efficiency of major crops in the Mediterranean region. Ann. Appl. Biol. 2007, 150, 281-291. [CrossRef]

32. Haghighi, M.; France, J.; Behboudian, M.H.; Mills, T.M. Fruit quality responses of 'Petopride' processing tomato (Lycopersicon esculentum Mill.) to partial rootzone drying. J. Hortic. Sci. Biotechnol. 2013, 88, 154-158. [CrossRef]

33. Birhanu, K.; Tilahun, K. Fruit yield and quality of drip-irrigated tomato under deficit irrigation. Afr. J. Food. Agric. Nutr. Dev. 2010, 10, 2139-2151. [CrossRef]

34. Valerio, M.; Lovelli, S.; Sofo, A.; Perniola, M.; Scopa, A.; Amato, M. Root and leaf abscisic acid concentration impact on gas exchange in tomato (Lycopersicon esculentum Mill.) plants subjected to partial root-zone drying. Ital. J. Agron. 2017, 12, 25-32. [CrossRef]

35. Nardella, E.; Giuliani, M.M.; Gatta, G.; De Caro, A. Yield response to deficit irrigation and partial root-zone drying in processing tomato (Lycopersicon esculentum Mill.). J. Agric. Sci. Technol. A 2012, 2, 209-219. [CrossRef]

36. Caliandro, A.; Lamaddalena, N.; Stelluti, M.; Steduto, P. Caratterizzazione Agro-Ecologica Della Regione Puglia in Funzione Della Potenzialità Produttiva; Ideaprint: Bari, Italy, 2005; ISBN 2-85352-339-X.

37. Allen, R.G.; Pereira, L.S.; Raes, D.; Smith, M. Crop Evapotranspiration: Guidelines for Computing Crop Water Requirements; Irrigation and Drainage, No. 56; FAO: Rome, Italy, 1998.

38. Tarantino, E.; Onofri, M. Determinazione dei coefficienti colturali mediante lisimetri. Bonifica 1991, 7, 119-136. 
39. Patanè, C.; Tringali, S.; Sortino, O. Effects of deficit irrigation on biomass, yield, water productivity and fruit quality of processing tomato under semi-arid Mediterranean climate conditions. Sci. Hortic. 2011, 129, 590-596. [CrossRef]

40. Istanbulluoglu, A.; Gocmen, E.; Gezer, E.; Pasa, C.; Konukcu, F. Effects of water stress at different development stages on yield and water productivity of winter and summer safflower (Carthamus tinctorius L.). Agric. Water Manag. 2009, 96, 1429-1434. [CrossRef]

41. Rinaldi, M.; Rana, G. I fabbisogni idrici del pomodoro da industria in Capitanata. Riv. Ital. Agrometeorol. 2004, 1, 31-35.

42. AOAC. Official Methods of Analysis; Association of Official Analytical Chemists: Washington, DC, USA, 1995.

43. AOAC. Official Methods of Analysis; Association of Official Analytical Chemists: Washington, DC, USA, 1990.

44. Francis, F.J.; Clydesdale, F.M. Food Colorimetry: Theory and Applications; AVI Publ. Co.: Westport, CT, USA, 1975.

45. Favati, F.; Lovelli, S.; Galgano, F.; Miccolis, V.; Di Tommaso, T.; Candido, V. Processing tomato quality as affected by irrigation scheduling. Sci. Hortic. 2009, 122, 562-571. [CrossRef]

46. Box, G.E.P.; Cox, D.R. An analysis of transformations. J. R. Stat. Soc. Ser. B Methodol. 1964, 26, $211-252$.

47. Bair, E.; Hastie, T.; Debashis, P.; Tibshirani, R. Prediction by supervised principal components. J. Am. Stat. Assoc. 2006, 101, 119-137. [CrossRef]

48. Affi, N.; El Fadi, A.; El Otmani, M.; Benismail, M.C.; Idrissib, L.M.; Salghi, R.; El Mastor, A. Comparative effects of partial rootzone drying and deficit irrigation on physiological parameters of tomato crop. Der Pharma Chem. 2012, 4, 2402-2407.

49. Zegbe-Domínguez, J.A.; Behboudian, M.H.; Lang, A.; Clothier, B.E. Deficit irrigation and partial rootzone drying maintain fruit dry mass and enhance fruit quality in 'Petopride' processing tomato (Lycopersicon esculentum, Mill.). Sci. Hortic. 2003, 98, 505-510. [CrossRef]

50. Zegbe, J.A.; Behbouidan, M.H.; Clothier, B.E. Partial rootzone drying is a feasible option for irrigating processing tomatoes. Agric. Water Manag. 2004, 68, 195-206. [CrossRef]

51. Campos, H.; Trejo, C.; Pena Valdivia, B.C.; Ramirez-Ayala, C.; Sanchez-Garcia, P. Effect of partial rootzone drying on growth, gas exchange, and yield of tomato (Solanum lycopersicum L.). Sci. Hortic. 2009, 120, 493-499. [CrossRef]

52. Expósito, A.; Berbel, J. Microeconomics of deficit irrigation and subjective water response function for olive groves. Water 2016, 8, 254. [CrossRef]

53. Kramer, P.J. Water Relations of Plants; Academic Press: New York, NY, USA, 1983; p. 489, ISBN 0-12-425040-8.

54. Mills, T.M.; Behboudian, M.H.; Clothier, B.E. The diurnal and seasonal water relations, and composition, of "Braeburn" apple fruit under reduced plant water status. Plant Sci. 1997, 126, 145-154. [CrossRef]

55. Kumar, S.; Rumanjini Gowda, P.H.; Mallikarjuna, N.M. Evaluation of selected $\mathrm{F}_{6}$ tomato lines for extended shelf life. SABRAO J. Breed. Genet. 2015, 47, 326-334.

56. Bogale, A.; Nagle, M.; Latif, S.; Aguila, M.; Müller, J. Regulated deficit irrigation and partial root-zone drying irrigation impact bioactive compounds and antioxidant activity in two select tomato cultivars. Sci. Hortic. 2016, 213, 115-124. [CrossRef]

57. Pulupol, L.U.; Behboudian, M.H.; Fisher, K.J. Growth, yield and postharvest attributes of glasshouse tomatoes produced under water deficit. Sci. Hortic. 1996, 31, 926-929.

58. Tohge, T.; Alseekh, S.; Fernie, A.R. On the regulation and function of secondary metabolism during fruit development and ripening. J. Exp. Bot. 2014, 65, 4599-4611. [CrossRef] [PubMed]

(C) 2017 by the authors. Licensee MDPI, Basel, Switzerland. This article is an open access article distributed under the terms and conditions of the Creative Commons Attribution (CC BY) license (http://creativecommons.org/licenses/by/4.0/). 